\title{
Rate and Uniformity of Herbaceous Perennial Seed Germination and Emergence as Affected by Priming
}

\author{
Dina Margaret Samfield, Jayne M. Zajicek², and B. Greg Cobb² \\ Department of Horticultural Sciences, Texas A\&M University College Station, TX 77843-2123
}

Additional index words. osmoconditioning, Coreopsis lanceolata, Echinacea pupurea, wildflowers

\begin{abstract}
Seeds of tickseed (Coreopsis lanceolata L.) and purple coneflower [Echinacea purpurea (L.) Moench] were primed in aerated solutions of distilled water or 50 or $100 \mathrm{mM}$ salt (potassium phosphate, pH 7.0) at 16C for 3, 6, 9, or 12 days. Coreopsis seeds primed in the $50 \mathrm{mM}$ buffer germinated the most rapidly and uniformly, and, under stress conditions in the greenhouse, resulted in a faster-growing, more-uniform crop than other treatments. Seeds primed in distilled water and the $50 \mathrm{mM}$ buffer germinated faster and at higher rates at suboptimal temperatures in the laboratory than nonprimed seeds. Priming of Echinacea purpurea seeds for 6 or 9 days in distilled water or in the $50 \mathrm{mM}$ buffer resulted in faster, more-uniform germination than other treatments. Seedling emergence under stress conditions was improved by all priming regimes, with best emergence occurring in treatments that lasted $>3$ days. Priming also increased germination rates of $E$. purpurea at suboptimal temperatures in the laboratory.
\end{abstract}

Texas wildflowers are desirable for their low maintenance requirements, erosion control, and aesthetic qualities. However, the seeds of many native plant species have relatively complex dormancy systems that help ensure reproduction and survival in nature, but pose some problems in propagation (Phillips, 1985). These seeds exhibit undesirable germination characteristics, such as wide variation in time from sowing to emergence and low percentage of total germination (Phillips, 1985). Osmoconditioning or seed priming techniques may be the best means of facilitating the use of native perennials in commercial production by enhancing features such as rapid germination, germination uniformity, and germination over a wide range of temperatures.

Priming has been used to improve the germination of vegetable crops for several years, yet little is known about its effects on the performance of seeds of ornamental species. For many vegetable crops, seed priming has speeded germination (Bradford, '1986; Brocklehurst and Dearman, 1983a), increased germination percentages (Bradford, 1986; Gray and Steckel, 1976), improved uniformity of germination (Bradford, 1986; Coolbear, 1980), and hastened the rate of seedling emergence following planting (Bradford, 1986; Brocklehurst and Dearman, 1983 b). In addition. seeds with specific temperature requirements can be primed 'for successful' germination over a wider range of temperatures (Atherton and Farooque, 1983; Bradford, 1986; Cantliffe et al., 1984; De Klerk, 1986; Rivas et al., 1984). A consistent improvement in time and synchronization of emergence achieved by osmotic seed priming has resulted in improved stands, increased plant fresh weight, and increased yield in various crops (Bradford, 1986). Other benefits of seed priming are accelerated emergence in heat-damaged seed, better plant development before harvest, earlier ripening, and improved emergence at high and low temperatures (Bradford, 1986). The purpose of this investigation was to determine priming regimes

\footnotetext{
Received for publication 17 Oct. 1988. Texas Agricultural Experiment Station Journal Article no. 24144. Use of a company or product name does not imply approval or recommendation of the product to the exclusion of others that may also be suitable. The cost of publishing this paper was defrayed in part by the payment of page charges. Under postal regulations, this paper therefore must be hereby marked advertisement solely to indicate this fact.

'Graduate student.

${ }^{2}$ Assistant professor.
}

that will enhance the germination of two native perennial speties - tickseed and purple coneflower - to improve their commercial potential.

\section{Materials and Methods}

Priming. Seeds of purple cone flower and tickseed (donated by Wildseed, Inc., Houston, Texas) were suspended in cheesecloth packets in aerated solutions of distilled water and 50 or $100 \mathrm{mM}$ potassium phosphate buffer $(\mathrm{pH} 7.0)$ at $16 \mathrm{C}( \pm 1 \mathrm{C})$ for $3,6,9$, or 12 days. The solutions were saturated with air circulated through plastic tubing connected to two 115-V PennPlax (Penn-Plax Plastic, Garden City, N. Y.) aquarium air pumps. After the priming treatments, the seeds were removed and examined. Treatments that resulted in $\geq 5 \%$ germination during priming were discarded. Seeds of the remaining treatments were rinsed thoroughly in distilled water and air-dried for $24 \mathrm{hr}$. Controls were the untreated dry seed of each species.

Germination in laboratory. Germination of seed as treated above was determined in darkness at $23 \pm 1 \mathrm{C}$. Seeds were placed on two layers of moistened (Whatman \#1) filter paper in covered $5.5-\mathrm{cm}$ petri dishes. Each dish contained 50 seeds, with three replicate dishes per treatment. Radicle emergence to $\approx 1.0 \mathrm{~mm}$ was scored as germination and was recorded at 24hr intervals for 14 days. The mean time to germination was calculated for the equation: $\mathrm{T}_{50}=\Sigma \mathrm{T}_{\mathrm{i}} \mathrm{N}_{\mathrm{i}} / \Sigma \mathrm{N}_{\mathrm{i}}$; where $\mathrm{N}_{\mathrm{i}}$ is the number of newly germinated seeds at time $\mathrm{T}_{\mathrm{i}}$ (Alvarado et al., 1987).

Emergence in greenhouse. Seeds were treated in the manner described above. Three replicates containing 25 seeds each per treatment were planted in germination trays at a depth of 1.5 $\mathrm{cm}$ in a soilless medium (Metro Mix 200, W.R. Grace, Fogelsville, Pa.). Ambient temperatures in the greenhouse averaged 23C (day)/18C (night). Daily emergence counts of the number of seedlings visible above the soil medium and the number of seedlings having reached a minimum height of $1.0 \mathrm{~cm}$ were taken for 28 days. Both the laboratory and greenhouse experiments were conducted as a $5 \times 4$ factorial plus a control in a completely randomized design. An analysis of variance was conducted on all data and contrasts including control vs. the other treatments. Linear and quadratic responses were also analyzed (SAS Institute, 1985). In cases where treatments were discarded because of germination during priming, data were analyzed two ways: 1) common treatments for duration or con- 
centration were analyzed and 2) all remaining treatments were pooled over either duration or concentration, depending on significant findings, and analyzed. Trends were similar for both analyses, so pooled data will be presented.

Temperature study. Seeds were treated in distilled water $(0$ $\mathrm{mM}$ ) or $50-\mathrm{mm}$ salt solutions for 3 or 6 days for tickseed and for 6 or 9 days for purple coneflower. Controls were the untreated dry seed of each species. Control and treated seeds were placed in 5.5-cm petri dishes on Whatman \#1 filter paper moistened with distilled water, and placed in the dark in growth chambers calibrated at $5^{\circ}$ increments from 15 to $30 \mathrm{C}$. Three replicate dishes of 50 seeds per treatment were used at each temperature. Daily germination counts were recorded in the same manner as in the previous laboratory study. The experiment was conducted as a $2 \times 2 \times 4$ factorial with a separate control in a completely randomized design. An analysis of variance was conducted and linear, quadratic, and cubic contrasts were cartied out.

\section{Results}

\section{Germination in laboratory}

Tickseed. Seeds were primed in distilled water for 6, 9, or 12 days, and in the 50-mM buffer for 9 or 12 days, germinated during priming, and were eliminated. Of the remaining treatments, the concentration of the priming solution was the significant factor in increasing the precocity of tickseed seed germination (Fig. 1).

Seeds treated in the $50-\mathrm{mM}$ solution began to germinate within the first $24 \mathrm{hr}$. By the 2 nd day, these seeds had a higher percentage of germination than that of any other treatment (Fig. 1). Priming in distilled water and the 50- and 100-mu salt solutions resulted in reductions of $\mathrm{T}_{50}$ (time to $50 \%$ germination) by $35 \%, 44 \%$, and $16 \%$, respectively, as compared to the dry

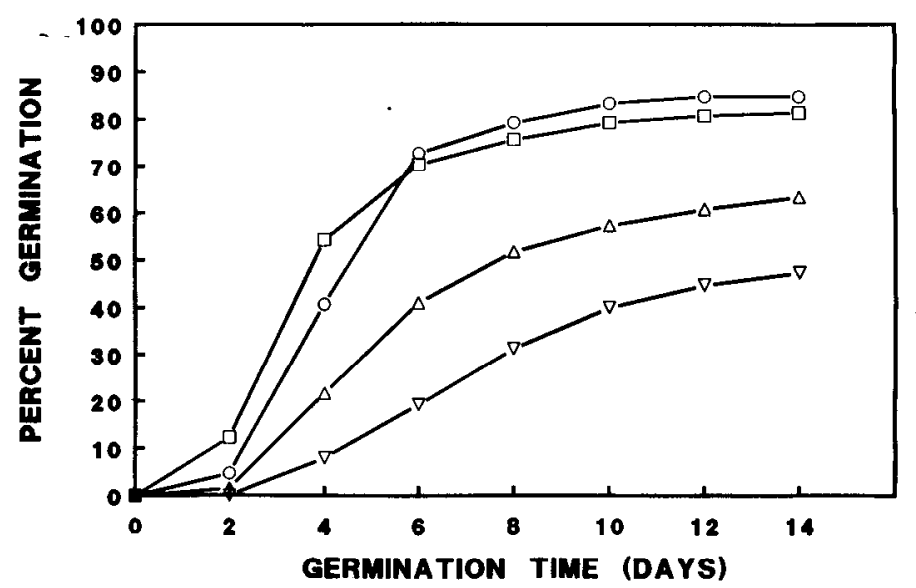

Fig. 1. Germination of tickseed at osmotic concentrations of $0(\mathrm{O})$, $50(\square), \quad$ or $100 \mathrm{~mm}(\triangle)$ potassium phosphate buffer. Control $(\nabla)$ seeds were not primed. Data pooled over all treatment durations. Each point is the mean of three replications (50 seeds per replication) per treatment duration.

NS, ${ }^{*}, * *, * * *$ Nonsignificant or significant at $P=0.05,0.01$, or 0.001 , respectively, via $\mathrm{F}$ test.

\begin{tabular}{lccccccccc} 
& df & \multicolumn{8}{c}{ Days } \\
\cline { 2 - 10 } Treatments & 3 & 2 & 4 & 6 & 8 & 10 & 12 & 14 \\
\hline Control vs. rest & 1 & NS & NS & $* * *$ & $* * *$ & $* *$ & $* *$ & $* *$ \\
Linear & 1 & NS & $* * *$ & $* * *$ & $* * *$ & $* * *$ & $* * *$ & $* * *$ \\
Quadratic & 1 & $*$ & $* *$ & $* *$ & $*$ & NS & NS & NS
\end{tabular}

control. Seeds primed in distilled water or in the 50-mm salt solutions had reached $89 \%$ and $91 \%$ of final germination by the end of the 1 st week, compared to $73 \%$ and $53 \%$ of maximum germination for the 100-mM-primed and control seeds, respectively. Seeds primed in distilled water for 3 days or in the 50$\mathrm{mM}$ buffer for 3 or 6 days also resulted in higher final germination percentages ( $85 \%$ and $81 \%$, respectively) than that of either the control seeds or those primed in the 100-mm salt concentration (47\% and $63 \%$, respectively).

Purple coneflower. Seeds primed for 12 days in distilled water germinated in solution and were discarded. Duration of treatment was found to have a highly significant effect on purple coneflower seed germination (Fig. 2). By day 2, seeds of the 9-day treatment had attained a higher percentage of germination than that of any other treatment. The nonprimed seeds did not begin to germinate until day 3, at which time seeds primed 6 or 9 days had reached $71 \%$ and $77 \%$ of their respective total germination counts. By the end of the first week, seeds of these two treatments had reached $\approx 99 \%$ of their final germination (94\% and $93 \%$, respectively), a higher level than that of the control ( $77 \%$ of final $83 \%$ germination). The 12 -day priming regime did improve precocity of germination over that of the control, but was less effective than the other three durations of treatment.

All durations of priming significantly reduced $\mathrm{T}_{50}$, as compared with the control. The 6- and 9-day treatments resulted in $41 \%$ and $47 \%$ reductions in $\mathrm{T}_{50}$, respectively, whereas the 3and 12-day treatments reduced $\mathrm{T}_{50}$ by $22 \%$ and $36 \%$.

\section{Emergence in greenhouse}

Tic/seed. The percentage of seedlings that reached a minimal height of $1 \mathrm{~cm}$ was similar to germination results obtained in the laboratory. Concentration of the osmotica had a significant effect on seedling growth; seedlings of seeds treated in the 50mm solution most rapidly grew to $1 \mathrm{~cm}$ or higher, and a higher

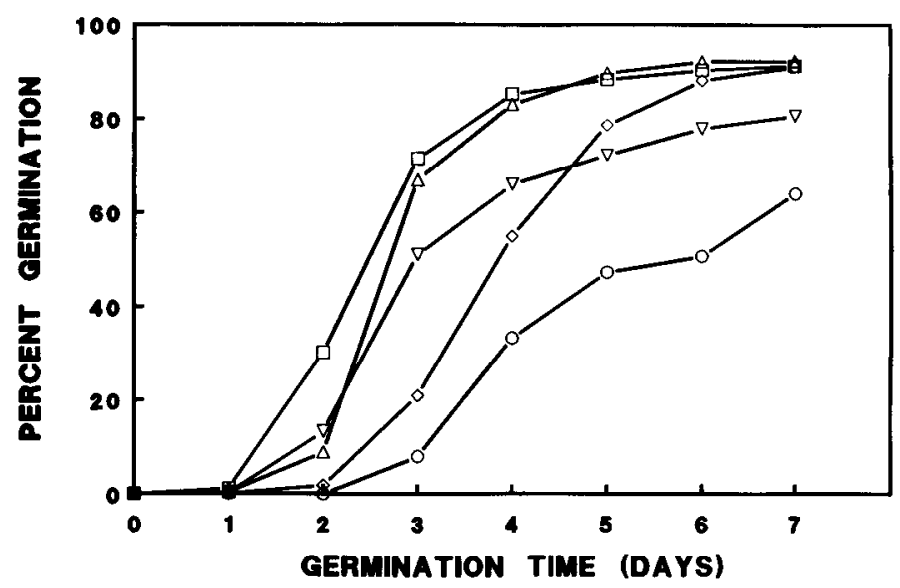

Fig. 2. Germination of purple coneflower at priming durations of 0 $(\bigcirc), 3(\diamond), 6(\Delta), 9(\square)$, and $12(\nabla)$ days. Data pooled over all treatment concentrations. Each point is the mean of three replications (50 seeds per replication) per treatment concentration.

NS*,**,***Nonsignificant or significant at $P=0.05,0.01$, or 0.001 , respectively, via $\mathrm{F}$ test.

\begin{tabular}{lcccccccc} 
& df & \multicolumn{8}{c}{ Days } \\
\cline { 2 - 9 } Treatments & 3 & 2 & 4 & 6 & 8 & 10 & 12 & 14 \\
\hline Control vs. rest & 1 & NS & $* * *$ & $* * *$ & $* * *$ & $* * *$ & $* * *$ & $* * *$ \\
Linear & 1 & NS & $* * *$ & NS & $* *$ & $* *$ & $* * *$ & $* * *$ \\
Quadratic & 1 & NS & $* * *$ & $* * *$ & $* *$ & $* *$ & $* *$ & $* *$
\end{tabular}


percentage than in the other treatments reached or exceeded 1 $\mathrm{cm}$ from day 18 until the end of the experiment at 28 days (Fig. 3 ). By the 28th day from sowing, $71 \%$ of seeds primed in the $50-\mathrm{mM}$ buffer had emerged above the growing medium, $42 \%$ of which were $\geq 1 \mathrm{~cm}$ in height. At the same time, $21 \%$ of the $56 \%$ of the control seedlings having emerged above "the soil medium were $\geq 1 \mathrm{~cm}$ in height, compared with $13 \%$ of $63 \%$ for those primed in $100-\mathrm{mM}$ salt solution and $16 \%$ of $76 \%$ for those seeds primed in distilled water.

Purple coneflower. As was evident in the laboratory germination study, duration of treatment was clearly the most significant aspect of priming to affect seedling growth. By the 18th day from sowing, duration of treatment was significant and remained so throughout the remainder of the emergence study (Fig. 4). The 9- and 12-day treatments improved seedling height over that of the 3-day treatment or the nonprimed control. The control seedlings did not begin to attain a height of $1 \mathrm{~cm}$ until after the 18th day from sowing, at which time the 9- and 12day priming treatments had resulted in a greater number of seedlings at that height than either the 3-day treatment or the control. By day $28,82 \%$ of all seeds treated for 9 days had emerged as seedlings, $79 \%$ of which were $\geq 1 \mathrm{~cm}$ high. The control seeds had emerged at a rate of $39 \%, 62 \%$ of which had attained a minimum-height of $1 \mathrm{~cm}$.

\section{Temperature study}

Tickseed. Only distilled water ( $0 \mathrm{mM})$, the $50-\mathrm{mM}$ salt buffer, and a dry control were used in this experiment, Temperature and concentration of the osmotica significantly affected percentage of seed germination throughout the duration of this study (Table 1). The seed primed in 50-mm salt buffer and germinated at 15 or $20 \mathrm{C}$ consistently maintained higher levels of germination than the other treatments throughout the first 8 days after sowing. At that time, the 50-mm treatments germinated at 15

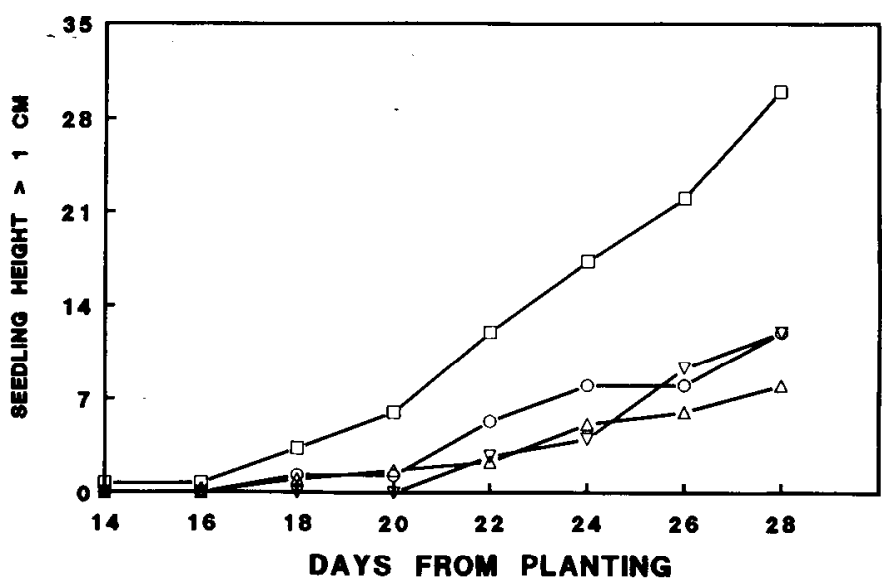

Fig. 3. Seedling growth of tickseed at osmotic concentrations of 0 $(\bigcirc), 50(\square)$, or $100 \mathrm{~mm}(\triangle)$ potassium phosphate buffer. Control $(\nabla)$ seeds were not primed. Data pooled over all treatment durations. Each point is the mean of three replications ( 25 seeds per replication) per treatment duration.

Ns, $* * *, * * *$ Nonsignificant or significant at $P=0.05,0.01$, or 0.001 , respectively, via $\mathrm{F}$ test.

\begin{tabular}{lcccccccc} 
& df & \multicolumn{7}{c}{ Days } \\
\cline { 3 - 9 } Treatments & 3 & 16 & 18 & 20 & 22 & 24 & 26 & 28 \\
\hline Control vs. rest & 1 & NS & NS & NS & NS & NS & NS & NS \\
Linear & 1 & NS & NS & NS & $*$ & $* *$ & $* *$ & $* *$ \\
Quadratic & 1 & NS & $*$ & $* *$ & $* * *$ & $* * *$ & $* * *$ & $* * *$
\end{tabular}

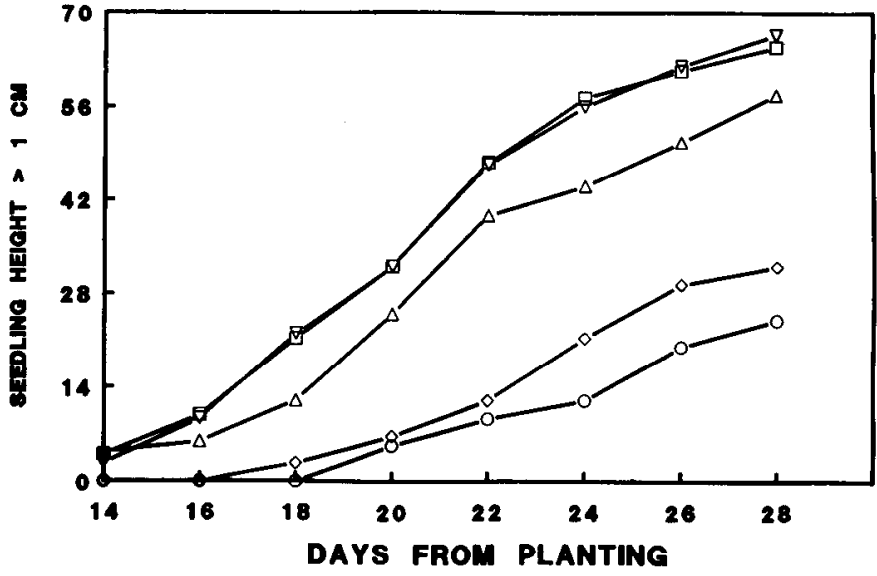

Fig. 4. Seedling growth of purple coneflower at priming durations of $0(\bigcirc), 3(\diamond), 6(\triangle), 9(\square)$, or $12(\nabla)$ days. Data pooled over all treatment concentrations. Each point is the mean of three replications (25 seeds per replication) per treatment concentration.

Ns.*.**,***Nonsignificant or significant at $P=0.05,0.01$, or 0.001 , respectively, via $F$ test.

\begin{tabular}{lcccccccc} 
& df & \multicolumn{7}{c}{ Days } \\
\cline { 3 - 9 } Treatments & 3 & 16 & 18 & 20 & 22 & 24 & 26 & 28 \\
\hline Control vs. rest & 1 & NS & $*$ & $* *$ & $* *$ & $* * *$ & $* * *$ & $* * *$ \\
Linear & 1 & $* *$ & $* * *$ & $* * *$ & $* * *$ & $* * *$ & $* * *$ & $* * *$ \\
Quadratic & 1 & NS & NS & NS & $* *$ & $* * *$ & $* *$ & $* *$
\end{tabular}

Table 1. Effects of temperature and osmotic concentration on seed germination of tickseed. ${ }^{2}$

\begin{tabular}{|c|c|c|c|c|}
\hline \multicolumn{2}{|c|}{ Priming conditions ${ }^{y}$} & & & \\
\hline \multirow{2}{*}{$\begin{array}{l}\text { Salt concn } \\
(\mathrm{mM})\end{array}$} & \multirow{2}{*}{$\begin{array}{c}\text { Temp } \\
\left({ }^{\circ} \mathrm{C}\right)\end{array}$} & \multicolumn{3}{|c|}{ Days from sowing } \\
\hline & & 4 & 8 & 12 \\
\hline & & Germ & $(\%)$ & \\
\hline \multirow[t]{4}{*}{ Control } & 15 & 0.0 & 6.7 & 30.7 \\
\hline & 20 & 0.7 & 12.7 & 28.0 \\
\hline & 25 & 0.7 & 10.0 & 21.3 \\
\hline & 30 & 2.0 & 4.0 & 10.7 \\
\hline \multirow[t]{4}{*}{0} & 15 & 4.3 & 21.0 & 35.7 \\
\hline & 20 & 6.3 & 18.3 & 32.7 \\
\hline & 25 & 8.0 & 19.7 & 28.7 \\
\hline & 30 & 3.0 & 11.7 & 17.7 \\
\hline \multirow[t]{4}{*}{50} & 15 & 5.4 & 28.3 & 39.0 \\
\hline & 20 & 11.7 & 25.0 & 32.0 \\
\hline & 25 & 8.3 & 18.3 & 27.3 \\
\hline & 30 & 2.0 & 6.3 & 9.3 \\
\hline \multicolumn{5}{|l|}{ Control } \\
\hline \multicolumn{2}{|l|}{ Linear } & NS & NS & * \\
\hline \multicolumn{2}{|l|}{ Quadratic } & NS & $* *$ & NS \\
\hline Cubic & & NS & NS & NS \\
\hline \multicolumn{5}{|l|}{$0 \mathrm{mM}$} \\
\hline \multicolumn{2}{|l|}{ Linear } & $* *$ & $* * *$ & $* * *$ \\
\hline \multicolumn{2}{|l|}{ Quadratic } & $* *$ & NS & NS \\
\hline \multirow{2}{*}{\multicolumn{5}{|c|}{$\begin{array}{l}\text { Cubic } \\
50 \mathrm{~mm}\end{array}$}} \\
\hline & & & & \\
\hline \multicolumn{2}{|l|}{ Linear } & ** & $* * *$ & $* * *$ \\
\hline \multicolumn{2}{|l|}{ Quadratic } & ** & NS & NS \\
\hline \multicolumn{2}{|l|}{ Cubic } & NS & NS & NS \\
\hline
\end{tabular}

${ }^{2}$ Data pooled over all duration levels per concentration of $\mathrm{K}_{2} \mathrm{HPO}_{4}+$ $\mathrm{KH}_{2} \mathrm{PO}_{4}$; control, nonprimed; $0 \mathrm{~mm}, 3$ or 6 days; $50 \mathrm{~mm}, 3$ or 6 days. ${ }^{y}$ Three replications of 50 seeds each per treatment.

Ns $* * * * * * *$ Nonsignificant or significant at $P=0.05,0.01$, or 0.001 , respectively, via $\mathrm{F}$ test. 
and 20C had reached higher germination percentages than all other treatments (Table 1).

Purple coneflower. Both temperature andconcentration significantly affected seed germination throughout the greater part of the experiment (Table 2). By day 8, at 20, 25, and 30C, seeds primed in distilled water had reached higher germination percentages than control seeds or seeds primed in $50-\mathrm{mM}$ buffer. At $15 \mathrm{C}$, the treated seeds achieved higher levels of germination than the dry control at 12 days.

\section{Discussion}

For both species, uniformity and advancement of germination was enhanced through priming. Previous studies on seed priming have clearly shown the advantages of this treatment in laboratories 'and greenhouses in improving seed vigor at suboptimal temperatures, notably in seeds with non-uniform germination (Heydecker et al., 1975; Heydecker and Coolbear, 1977).

The prolongation of priming made possible by lowering the water potential of the priming solution through the addition of salts extends the time in which the pregerminative metabolic

Table 2. Effects of temperature and osmotic concentration on seed germination of purple coneflower.

\begin{tabular}{|c|c|c|c|c|c|}
\hline \multicolumn{2}{|c|}{ Priming conditions $\mathbf{s}^{y}$} & & & & \\
\hline \multirow{2}{*}{$\begin{array}{l}\text { Salt concn } \\
(\mathrm{mM})\end{array}$} & \multirow{2}{*}{$\begin{array}{l}\text { Temp } \\
\left({ }^{\circ} \mathrm{C}\right)\end{array}$} & & \multicolumn{3}{|c|}{ Days from sowing } \\
\hline & & & 4 & 8 & 12 \\
\hline \multirow{5}{*}{ Control } & \multicolumn{5}{|c|}{ Germination (\%) } \\
\hline & 15 & 、 & 0.0 & 0.0 & 0.0 \\
\hline & 20 & & 0.0 & 25.3 & 48.7 \\
\hline & 25 & & 2.0 & 35.3 & 55.3 \\
\hline & 30 & & 0.7 & 25.3 & 30.7 \\
\hline \multirow[t]{4}{*}{0} & 15 & & 0.0 & 0.7 & 14.0 \\
\hline & 20 & & 13.0 & 63.0 & 70.3 \\
\hline & 25 & & 34.3 & 66.7 & 72.0 \\
\hline & 30 & & 32.0 & 62.7 & 66.7 \\
\hline \multirow[t]{4}{*}{$50^{-}$} & 15 & & 0.0 & 3.0 & 18.0 \\
\hline & 20 & & 17.0 & 57.3 & 63.7 \\
\hline & 25 & . & 26.7 & 55.0 & 57.0 \\
\hline & 30 & & 24.3 & 49.0 & 54.7 \\
\hline \multicolumn{6}{|l|}{ Control } \\
\hline Linear & & & $*$ & ** & $* *$ \\
\hline Quadratic & & & NS & $* *$ & $* *$ \\
\hline Cubic & & & NS & NS & NS \\
\hline \multicolumn{6}{|l|}{$0 \mathrm{~mm}$} \\
\hline Linear & & & $* * *$ & $* * *$ & $* * *$ \\
\hline Quadratic & & & $* * *$ & $* * *$ & $* * *$ \\
\hline Cubic & & & $* *$ & $* *$ & $* * *$ \\
\hline \multicolumn{6}{|l|}{$50 \mathrm{mM}$} \\
\hline Linear & & & $* * *$ & $* * *$ & $* * *$ \\
\hline Quadratic & & & $* * *$ & $* * *$ & $* * *$ \\
\hline Cubic & & & NS & $*$ & $* *$ \\
\hline
\end{tabular}

${ }^{2}$ Data pooled over all duration levels per concentration of $\mathrm{K}_{2} \mathrm{HPO}_{4}+$ $\mathrm{KH}_{2} \mathrm{PO}_{4}$; control, unprimed; $0 \mathrm{~mm}, 6$ or 9 days; $50 \mathrm{mM}, 6$ or 9 days. 'Three replications of 50 seeds each per treatment.

Ns $*, * *, * * *$ Nonsignificant or significant at $P=0.05,0.01$, or 0.001 , respectively, via $\mathrm{F}$ test. processes can occur within the seed (Heydecker and Coolbear, 1977). This effect may explain the increased benefits of the salt treatments under adverse emergence conditions, such as relatively deep planting and suboptimal temperatures for both species. In the laboratory, seeds of tickseed primed in distilled water had higher germination percentages and germinated more uniformly than nonprimed seed (Fig. 1). In the greenhouse, however, this increase was not as pronounced (Fig. 3). For purple coneflower, 6 and 9 days of priming gave the best results in the laboratory (Fig. 2), but in the greenhouse it was the 12day priming treatment that improved seed germination compared to the other treatments and the dry control (Fig. 4).

The results described here indicate that priming in a $50-\mathrm{mm}$ potassium phosphate buffer for 3 to 6 days for tickseed and for 6 to 9 days for purple coneflower is a simple, effective, and inexpensive means of ensuring a more precocious, uniform, and vigorous germination for both species than if plants were started from nonprimed seed. Because percentage of germination and emergence of purple coneflower were not significantly affected by osmotic concentration, distilled water maybe as effective as salt in increasing the rate and uniformity of seed germination.

\section{Literature Cited}

Atherton, J.G. and A.M. Farooque. 1983. High temperature and germination in spinach: II. Effects of osmotic priming. Scientia Hort. 19:221-227.

Bradford, K.J. 1986. Manipulation of seed water relations via osmotic priming to improve germination under stress conditions. HortScience 21(5):1105-1112.

Brocklehurst, P.A. and J. Dearman. 1983a. Interactions between seed priming treatments and nine seed lots of carrot, celery, and onion: 1. Laboratory germination. Ann. Applied Biol. 102:577-584.

Brocklehurst, P.A. and J. Dearman. 1983b. Interactions between seed priming treatments and nine seed lots of carrot, celery, and onion: 11. Seedling emergence and plant growth. Ann. Applied Biol. 102:585593.

Cantliffe, D. J., J.M. Fischer, and T.A. Nell. 1984. Mechanism of seed priming circumventing thermodormancy in lettuce. Plant Physiol. 75:290-294.

Coolbear, P. 1980. Osmotic pre-sowing treatments and nucleic acid accumulation in tomato seeds (Lycopersicon lycopersicum). Seed Sci. Technol. 8:289-303.

De Klerk, G.J. 1986. Advantageous and detrimental effects of osmotic pre-sowing treatment on the germination performance of Agrostemma githago seeds. J. Expt, Bet. 37(179):765-774.

Gray, D. and J.R.A. Steckel. 1976. The effects of pre-sowing seed treatments on the germination and emergence of lettuce seeds at high salt concentrations. Scientia Hort. 5:1-9.

Heydecker, W. and P. Coolbear. 1977. Seed treatments for improved performance - survey and attempted prognosis. Seed Sci. Technol. $5: 353-425$.

Heydecker, W., J. Higgins, and V.J. Turner. 1975. Invigoration of seeds? Seed Sci. Technol. 3:881-888.

Phillips, H.R. 1985. Growing and propagating wild flowers. Univ. of North Carolina Press, Chapel Hill.

Rivas, M., F.J. Sundstrom, and R.L. Edwards. 1984. Germination and crop development of hot pepper after seed priming. HortScience 19(2):279-281.

SAS Institute. 1985. SAS user's guide: Statistics. 5th ed. SAS Institute, Inc. Cary, N.C. 